\title{
PRELIMINARY INVESTIGATION ON PERFORMANCE OF PHOTODIODE SENSOR AS A DOSIMETER
}

\author{
Md Radzi Y., Zulkafli N., Omar A. \\ Universiti Sains Malaysia, Malaysia
}

\begin{abstract}
Radiation dosimetry in the health and medicine field is crucial to ensure there is no unnecessary ionizing radiation exposure to patients and personnel. While various types of semiconductor dosimeters are available, photodiode sensors are seen as a reliable and cost-effective immediate dosimeter. This study investigates the capabilities of a monolithic photodiode with an on-chip trans-impedance amplifier as a dosimeter in diagnostic radiology. A photodiode sensor covered with black insulation tape is irradiated with the diagnostic $x$-ray of potential in range between 40 to $90 \mathrm{kV}$ with constant tube current-time product of $50 \mathrm{mAs}$ at $60 \mathrm{~cm}$ source-to-detector distance (SDD). Exposures of different tube current at the range of 10 to $250 \mathrm{~mA}$ with a constant tube voltage of $70 \mathrm{kVp}$ at the same setup are made. The photodiode sensor connected to the electrometer gives out readings in the millivolt $(\mathrm{mV})$, and the output of the photodiode and semiconductor detector is recorded. The photodiode's energy dependency, reproducibility, dose response, and distance dependency were evaluated as the capabilities of the photodiode to be used as a dosimeter. For energy dependency, it shows a linearity of 0.9458 , while the response to increasing tube current with a constant tube voltage shows the $R^{2}$ of 0.912 . The photodiode shows good dependency on the tube voltage and tube current. Other than that, it also showed a linear coefficient of 0.5138 for distance dependence which is considered as a good linearity fit value for a photodiode as initial performance. However, its reproducibility is poor due to its large capacitance. This monolithic photodiode with an on-chip trans-impedance amplifier has demonstrated good results for energy dependency but poor results for reproducibility. However, the photodiode can be improvised in the future to ensure it is suitable as a dosimeter.
\end{abstract}

Keywords: radiation dosimetry, dosimeter, photodiode sensor.

For citations: Md Radzi Y., Zulkafli N., Omar A. Preliminary investigation on performance of photodiode sensor as a dosimeter, Biomedical Photonics, 2021, vol. 10, No 1, pp. 4-10. doi: 10.24931/2413-9432-2021-10-1-4-10

Contacts: Md Radzi Y., email: yasminradzi@usm.my

\section{ПИЛОТНОЕ ИССЛЕДОВАНИЕ ЭФФЕКТИВНОСТИ ИСПОЛЬЗОВАНИЯ ФОТОДИОДНОГО СЕНСОРА В КАЧЕСТВЕ ДОЗИМЕТРА}

\author{
Md Radzi Y., Zulkafli N., Omar A. \\ Научный университет Малайзии, Малайзия
}

\section{Резюме}

Дозиметрия излучения в области здравоохранения и медицины имеет решающее значение для предотвращения ненужного воздействия ионизирующего излучения на пациентов и персонал. Несмотря на доступность различных типов полупроводниковых дозиметров, фотодиодные датчики считаются надежными и экономичными непосредственными дозиметрами. В этом исследовании изучаются возможности использования монолитного фотодиода со встроенным трансимпедансным усилителем в качестве дозиметра в диагностической радиологии. Фотодиодный датчик, покрытый черной изоляционной лентой, облучался диагностическим рентгеновским излучением в диапазоне напряжений на излучателе от 40 до 90 кВ с постоянной экспозицией 50 мАс с расстояния в 60 см до детектора (SDD). На одной и той же установке производятся воздействия различного тока трубки в диапазоне от 10 до 250 мА с постоянным напряжением трубки 70 кВ. Фотодиодный датчик, подключенный к электрометру, выдает показания в милливольтах (мB), а выходной сигнал фотодиода и полупроводникового детектора записывается. Энергетическая чувствительность фотодиода, воспроизводимость, реакция на дозу и зависимость от расстояния были оценены как возможности фотодиода для использования в качестве дозиметра. Для зависимости от энергии он показывает линейность 0,9458, в то время как для реакции на увеличение тока трубки при постоянном напряжении трубки $\mathrm{R}^{2}$ равен 0,912. Фотодиод показывает хорошую зависимость от напряжения лампы и тока трубки. Помимо этого, он также показал линейный коэффициент 0,5138 для зависимости от расстояния, который считается хорошим значением при линейной подгонке для фотодиода в качестве начальных характеристик. Однако его воспроизводимость недостаточно высока из-за большой емкости. Таким образом, изучаемый монолитный фотодиод со встроенным трансимпедансным усилителем показал хорошие результаты по энергетической зависимости, но низкие результаты по воспроизводимости. Тем не менее, в будущем фотодиод может быть усовершенствован, чтобы обеспечить его пригодность в качестве дозиметра. 
Ключевые слова: радиационная дозиметрия, дозиметр, фотодиодный датчик.

Для цитирования: Md Radzi Y., Zulkafli N., Omar A. Пилотное исследование эффективности использования фотодиодного сенсора в качестве дозиметра // Biomedical Photonics. - 2021. - T. 10, № 1. - С. 4-10. doi: 10.24931/2413-9432-2021-10-1-4-10

Контакты: Md Radzi Y., email: yasminradzi@usm.my

\section{Introduction}

Radiation dosimetry is an important method to measure the exposure of ionizing radiation to the patients, personnel, and the public. To measure and evaluates the ionizing radiation, a radiation detector or dosimeter is used. The dosimeter is the essential equipment required for radiation detection, especially in radiation monitoring and radiation protection. Radiation detectors or dosimeters operate in three types of operation modes which are pulse mode, current mode, and voltage mode. The most common mode of dosimeters is the pulse mode. For pulse mode, the signal from each interaction is processed individually. Thus, it is impractical for high event rates because it will increase the dead time, and a lot of signals could not be detected [1]. There are properties that a dosimeter must possess at least one for it to function as a radiation dosimeter, which are linearity, precision and accuracy, dose rate dependence, energy dependence, and directional dependence. In the market, nowadays, various dosimeters had been developed over the years, which can be used in specific energy range, type of radiation, and type of detection. There are radiation detectors that provide instant read-outs like survey meters and display accumulated exposure doses such as optically stimulated luminescence (OSL) dosimeter and thermal luminescence dosimeter (TLD). The one that provides instant reading is generally used in radiation protection to inspect leakage or spillage of the radioactive source. TLD and OSLD are the essential dosimeter that is compulsory for workers in the radiation-related department like in the oncology department and diagnostic radiology department.

There are various types of dosimeters, such as gasfilled detectors and semiconductor detectors. GeigerMuller survey meter is one kind of gas-filled dosimeter that operates in the Geiger-Muller region. Farmer's type of ionization chamber (IC) is another type of gas-filled detector. It is used in quality assurance in radiotherapy. For semiconductor detectors, there are metal-oxide semiconductor field effect transistors (MOSFET) and silicon diode dosimetry. Both semiconductor detectors are generally used for in-vivo dosimetry in radiotherapy due to their small sizes and good energy resolution.

The Silicon diode dosimetry system is used in clinical dosimetry for measurements of depth-dose, dose profiles, and output factors. It is increasingly used for small field dosimetry in modern therapy techniques as they have a very small size of the sensitive volume [2]. Silicon diodes have found utility in radiation dosimetry principally because a diode produces a current approximately 18,000 times that of an ionization chamber of equal sensitive volume [3]. It is mentioned by Yarahmadi, M. et al., that diode has high spatial resolution and high sensitivity, but it gives response dependence to energy [2]. Unlike MOSFET, the silicon diode dosimetry system is harder to set up since they required a long wire connected from them to the reader for read-out since it provides immediate read-out that is not recorded by any system.

The photodiode is the alternative to the silicon diode dosimeter because it has small size, real-time operation, low cost, high accuracy, and precision attainable in a wide range of doses [4]. The only lack of photodiode is its sensitivity that varied with temperature, dose rate, and its efficiency degrades over time.

Photodiodes have been widely used in biomedical application as $\mathbf{x}$-ray detectors in CAT scan, analyzers of blood particles, as well as pulse oximeters due to their excellent properties of fast response times at absolutely low cost compared to TLDs.

In this study, photodiode sensitivity is evaluated by comparing the OPT101 photodiode to the commercialized semiconductor detector, PTW detector. The photodiode is selected as an alternative device for silicon diode dosimetry due to its fundamental properties, which are energy dependency and dose linearity.

In terms of energy dependency, a study conducted by Oliveira, where they used four photodiodes with different specifications, found that there is a higher dependency in the $33 \mathrm{keV}$ up to $100 \mathrm{keV}$ energy range, but it could be the result of attenuation due to the coatings [5]. The other two studies found that the photodiode output increases with the tube voltage at the maximum energy of X-rays $[4,6]$. For dose linearity, a study by Paschoal, Souza, and Santos found that the tested BPW 345 photodiode presents a linear response with air kerma [7]. Also, another study used photodiode and found that the output of photodiode linearly proportional to the dose delivered [4]. Therefore, the objectives of this study are to analyze the reproducibility and consistency of OPT101 photodiode performances and to evaluate the OPT101 photodiode efficiency and sensitivity. 


\section{Materials and methods}

The OPT101 monolithic photodiode with a builtin transimpedance amplifier, as shown in Fig. 1, is used as the sensor for detecting the ionizing radiation from the $x$-ray machine. This photodiode has a sensitive area of $2.29 \mathrm{~mm} \times 2.29 \mathrm{~mm}$ and a large capacitance of 1200 pF. It has high responsitivity to the ambient light with a wavelength of $650 \mathrm{~nm}$. The OPT101 photodiode is connected to the digital multimeter to obtain the output response of the photodiode after being irradiated with the $\mathrm{x}$-rays from Toshiba KX0-50s x-ray machine with energy range from $40 \mathrm{kV}$ to $90 \mathrm{kV}$. At $60 \mathrm{~cm}$ source-to-detector distance (SDD), a semiconductor detector is also placed to measure the dose received by the photodiode. The OPT101 photodiode and PTW semiconductor detector are placed side-by-side with the same separation from the center of the light field. They are not placed along with the direction of the x-ray tube (anode-cathode) due to the anode heel effect. The PTW detector is connected to an electrometer and gives a read-out in $\mathrm{mGy}$ unit. The results obtained from the PTW detector and photodiode are compared to investigates the capabilities of the photodiode as a dosimeter.

To ensure the result obtained is not influenced by the ambient light, the photodiode is covered with black tape since the photodiode is sensitive to the ambient light and high responsitivity to the light with a wavelength of $650 \mathrm{~nm}$. Other than that, a lead shield is placed below the photodiode and PTW semiconductor detector to reduce the backscattered radiation from the table. Without the lead shield, the result obtained may be influenced by the backscattered radiation and leads to increases in readings. The value of non-irradiated output voltage of the photodiode indicated by the multimeter was initially recorded for control purposes.

To evaluate the photodiode performance as a dosimeter, the characterization of the photodiode is assessed. Energy dependence, dose response, distance dependence, and reproducibility of the photodiode are tested. Also, the sensitivity of the photodiode is analyzed by comparing it to a commercialized semiconductor detector, R/F/D PTW semiconductor detector.

The setup for energy dependence, dose response, reproducibility, and sensitivity are the same (Fig. 1). However, for energy dependence and sensitivity tests, the tube potential is increased from $40 \mathrm{kVp}$ to $90 \mathrm{kVp}$ with $10 \mathrm{kVp}$ increment with a fixed tube current of $50 \mathrm{~mA}$. The graph of output-dose response is obtained to evaluate the rate of output response increment with dose, while for the dose response test, the tube current increases from 10 $\mathrm{mA}$ to $250 \mathrm{~mA}$ with fixed tube potential of $70 \mathrm{kVp}$. For the reproducibility test, where the exposure factors are fixed at $70 \mathrm{kVp}$ and $50 \mathrm{mAs}$, three exposures are made every day for five consecutive days. The distance dependency test is performed with fixed exposure factors of $70 \mathrm{kVp}$

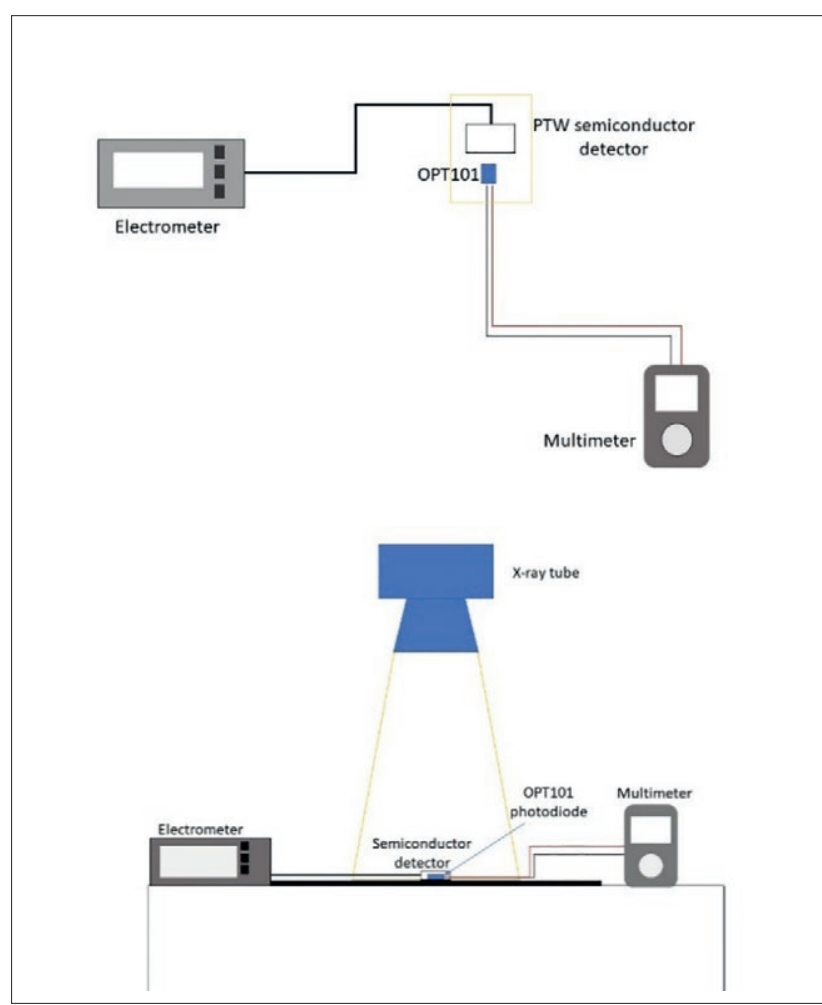

Fig. 1. Experimental setup of photodiode and semiconductor detector under the x-ray irradiation

Рис. 1. Экспериментальная установка для исследования фотодиода и полупроводникового детектора в поле рентгеновского излучения

and $50 \mathrm{mAs}$, with increasing SDD from $60 \mathrm{~cm}$ to $100 \mathrm{~cm}$ with $10 \mathrm{~cm}$ increment. For the sensitivity test, where the dose of the photodiode is compared to the dose by the PTW R/F/D semiconductor detector, the rate of output increases with the dose of the dose-output response is extracted. The characterization of the photodiode is analyzed based on the result obtained. The obtained data were plotted with a standard error of $5 \%$.

\section{Results}

Energy dependency

The value of non-irradiated photodiode was recorded to be $-1.232 \mathrm{mV}$. In the energy dependence study, where the tube potential increases by a step of 10 with a fixed tube current of $50 \mathrm{~mA}$, the result in Fig. 2 showed a linear coefficient of 0.9458 , which is a good linear fit value. Fig. 2 also shows the output response of OPT101 photodiode as the tube voltage increases from $40 \mathrm{kVp}$ to $90 \mathrm{kVp}$. Based on the graph, the output response of photodiode for $40 \mathrm{kVp}$ is greater than $50 \mathrm{kVp}$, and at 60 $\mathrm{kVp}$ and above, the output responses increase with tube potential.

\section{Dose response}

Fig. 3 presents the result of the output response of OPT101 photodiode with increasing tube current and 
fixed tube potential of $70 \mathrm{kVp}$. The graph shows the increasing pattern of the output signals as the tube current increases.

As the tube current increases from $10 \mathrm{~mA}$ to $20 \mathrm{~mA}$, the increment of the output signals is quite small; however, the output signal started increasing above $50 \mathrm{~mA}$ to $250 \mathrm{~mA}$. The linear coefficient for dose response of OPT101 photodiode is 0.912 , which is a good linearity fit value.

\section{Distance dependency}

Fig. 4 shows the output signals of the OPT101 photodiode as the distance between the photodiode and the $x$-ray source increasing from $60 \mathrm{~cm}$ to $100 \mathrm{~cm}$ with a 10 $\mathrm{cm}$ increment. At $100 \mathrm{~cm} \mathrm{SDD}$, the output signal is the lowest while at $70 \mathrm{~cm} \mathrm{SDD}$, the output signal is the highest. The linear coefficient for the distance dependence test is 0.5012 , which is considered a low linearity fit value; however, it is good enough for a performance of a photodiode. The highest deviation is 1.721 of $70 \mathrm{~cm} \mathrm{SDD}$, while the lowest deviation is 0.404 of $80 \mathrm{~cm}$ SDD.

\section{Reproducibility}

Fig. 5 presents the reproducibility of the output response of OPT101 photodiode with the same technical factors of $70 \mathrm{kVp}, 50 \mathrm{mAs}$, and $60 \mathrm{~cm} \mathrm{SDD}$. The readings were taken for five consecutive days. The graph shows the polynomial fit coefficient for reproducibility is 0.9247 and a standard deviation of 2.022. Contrarily, a degradation of dose accumulation was recorded for the period of 5 days.

\section{Sensitivity}

Fig. 6 presents the graph of output response to dose with a linear coefficient of 0.9711 , which shows that the output response of photodiode proportional to dose. The higher the dose, the greater the output signal detected by the photodiode. Fig. 7 presents the graph for measured doses of OPT101 photodiode and PTW detector. The dose measured by the PTW detector increases as the energy increases. However, for the photodiode, the increase of output signals as the energy increases are not noticeable. In terms of sensitivity, the PTW detector is more sensitive than the OPT101 photodiode since the slope of the increment of the dose is steeper than the slope of the photodiode.

\section{Discussion}

For the energy dependence test, where the tube potential increases from $40 \mathrm{kVp}$ to $90 \mathrm{kVp}$, the output response of the photodiode increases with the tube potential. Tube potential indicates the energy of the photons. The greater the tube potential, the higher the energy of the photons. Thus, the photodiode's output response increases as the energy increases. A study by Nazififard, Suh and Mahmoudieh also has the same finding where they

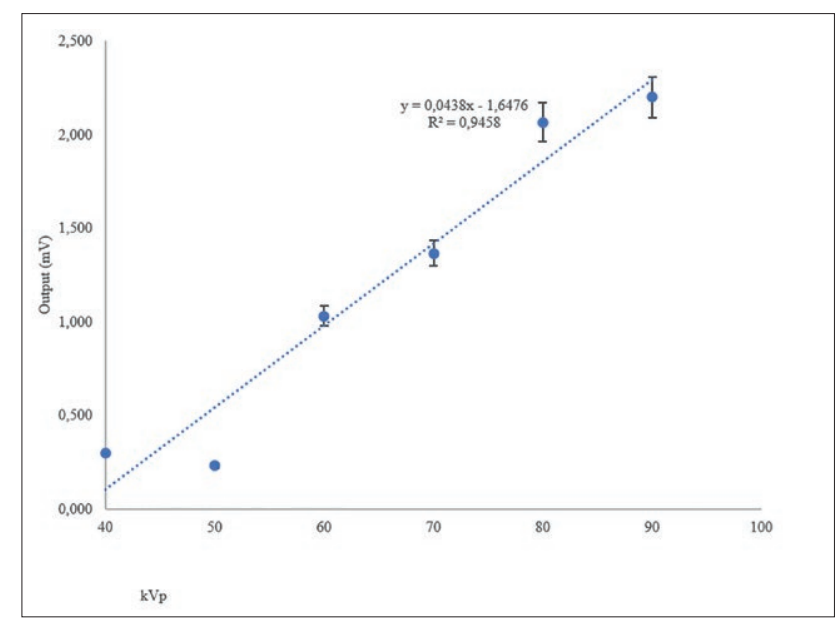

Fig. 2. Output response of photodiode as tube potential increases Рис. 2. Выходной отклик фотодиода при увеличении потенциала излучателя

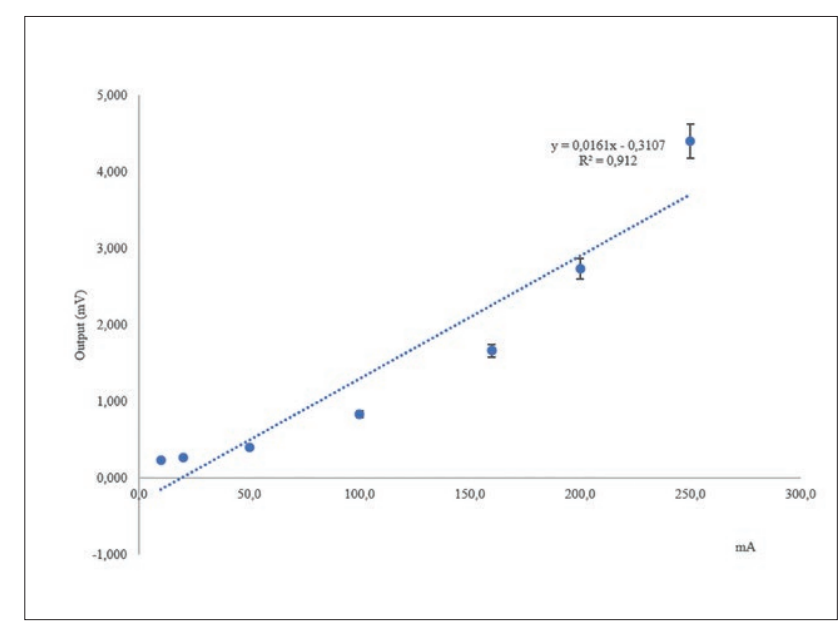

Fig. 3. Output response of photodiode with varied tube current Рис. 3. Выходная характеристика фотодиода при изменении тока на излучателе

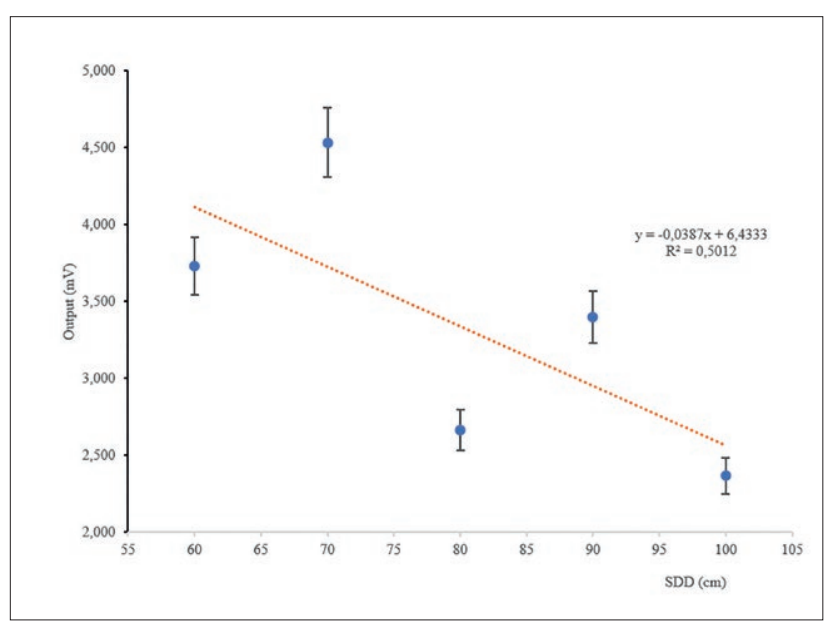

Fig. 4. Output response of photodiode to variation in distance Рис. 4. Выходной отклик фотодиода на изменение расстояния 

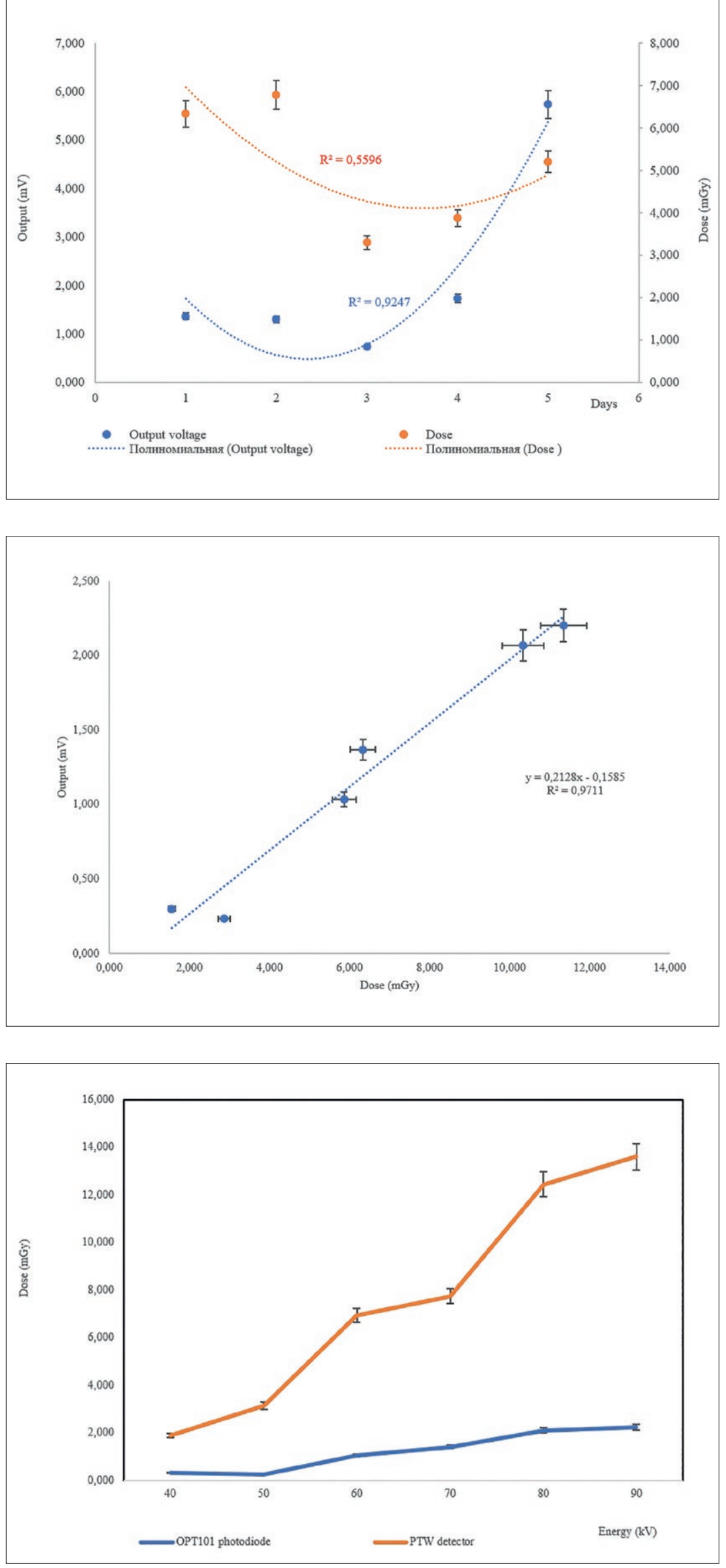

Fig. 5. The result for reproducibility of the photodiode for five consecutive days with deterioration of dose in mGy. Data were presented in polynomial fit and $5 \%$ standard error bar

Рис. 5. Результат воспроизводимости показаний фотодиода в течение пяти дней подряд с ухудшением дозы в мГр. Данные представлены в виде полиномиальной аппроксимации и шкалы стандартной ошибки $5 \%$

Fig. 6. Output response to increasing dose Рис. 6. Отклик на увеличение дозы

Fig. 7. Comparison of dose between R/F/D PTW semiconductor detector and OPT101 photodiode

Рис. 7. Сравнение дозы между полупроводниковым детектором R / F / D PTW и фотодиодом ОРТ101 
stated that the PIN photodiode output increases with tube potential that is the maximum energy of $x$-rays [6].

In dose response test, radiation exposure is made at a fixed $70 \mathrm{kVp}$ and increasing tube current, from $10 \mathrm{~mA}$ to $250 \mathrm{~mA}$. The tube current indicates the number of photons. Therefore, the higher the tube current, the greater the number of radiation-generated carriers collected by the electrometer since the number of photons increases with tube current. The good linear coefficient for increasing tube current for OPT101 photodiode coincides with the findings from Damulira's study where the number of charges drift in PN junctions was linear to the number of photons in the x-ray beam [8].

Distance plays a role in measuring radiation exposure. Based on inverse square law, where the greater the distance between the $\mathrm{x}$-ray source and the detector, the lower the intensity of radiation. In this work, the tested photodiode showed a linear coefficient of 0.5138 on the increasing distance, SDD due to the high capacitance of photodiode. The linear fit value is considered a good response for varied distances for a photodiode. The distance dependence of the photodiode is related to the Compton effect and photoelectric effect that occurs during the irradiation of the photodiode.

OPT101 photodiode showed a potentially good reproducibility when it was tested for five consecutive days. The discharge of stored charges in the capacitance within the photodiode leads to fluctuation of the output signal of the photodiode, which resulted in a slight deviation. There is no known justification yet for the inception between the dose accumulation and output response in the reproducibility test. However, the early hypothesis can be made that saturation point of the output and radiation dose is achieved, which where the photodiode can no longer be used as a dosimeter.

\section{REFERENCES}

1. Seco, J., Clasie, B., \& Partridge, M. Review on the characteristics of radiation detectors for dosimetry and imaging. Physics in Medicine and Biology, 2014, Vol. 59(20), pp. 303--347. https://doi. org/10.1088/0031-9155/59/20/R303

2. Yarahmadi, M., Wegener, S., \& Sauer, O. A. Energy and field size dependence of a silicon diode designed for small-field dosimetry. Medical Physics, 2016, Vol. 44 (5), pp. 1958-1964. https://doi. org/10.1002/mp.12195

3. Dixon, R. L., \& Ekstrand, K. E. Silicon diode dosimetry. The International Journal of Applied Radiation And Isotopes, 1982, Vol. 33(11), pp. 1171-1176. https://doi.org/10.1016/0020-708X(82)90242-3

4. Romei, C., Di Fulvio, A., Traino, C. A., Ciolini, R., \& d'Errico, F. Characterization of a low-cost PIN photodiode for dosimetry in diagnostic radiology. Physica Medica, 2015, Vol. 31(1), pp. 112-116. https://doi.org/10.1016/j.ejmp.2014.11.001

5. Oliveira, C. N. P., Khoury, H. J., \& Santos, E. J. P. PiN photodiode performance comparison for dosimetry in radiology applications. Physica Medica, 2016, Vol. 32(12), pp. 1495-1501. https:// doi.org/10.1016/j.ejmp.2016.10.018
Dose-output response has been observed to be proportional to the increasing energy. This is supported by a statement that sensitivity loss as a function of radiation damage depends on the photodiode's characteristics, the energy of the source, and the total absorbed dose [9]. Moreover, the radiation-induced current of photodiodes only flows during the exposure, thus giving a direct measurement/output electric signal [10]. This implies that photodiodes are active and real-time dosimeters [9].

Lastly, the OPT101 photodiode has poor sensitivity since the increased dose measured by the photodiode is small and not noticeable due to the low output signals compared to PTW detector. To increase the output response of the photodiode, adding multiple photodiodes will improve the sensitivity.

\section{Conclusion}

In this paper, the experimental evaluation of the OPT101 photodiode is performed to assess its performance as an immediate dosimeter. The OPT101 photodiode displays a good linear coefficient for energy dependence and dose response. For distance dependence, even though the linear coefficient is poor, it is considered good enough for a photodiode. The response of the photodiode to distance still could be improved further. The OPT101 photodiode also showed good reproducibility and sensitivity. Since OPT101 photodiode possesses the properties of a good semiconductor dosimeter, further study could be performed to enhance the capability of it to be used as an immediate dosimeter also the development of biomedical application in the future.

\section{Acknowledgments}

The authors appreciate the School of Physics, Universiti Sains Malaysia for full support of this project.

\section{ЛИТЕРАТУРА}

1. Seco, J., Clasie, B., \& Partridge, M. Review on the characteristics of radiation detectors for dosimetry and imaging // Physics in Medicine and Biology. - 2014. - Vol. 59(20). P. 303-347. https:// doi.org/10.1088/0031-9155/59/20/R303

2. Yarahmadi, M., Wegener, S., \& Sauer, O. A. Energy and field size dependence of a silicon diode designed for small-field dosimetry // Medical Physics. - 2016. - Vol. 44 (5). - P. 1958-1964. https://doi.org/10.1002/mp.12195

3. Dixon, R. L., \&Ekstrand, K. E. Silicon diode dosimetry//The International Journal of Applied Radiation And Isotopes. - 1982. - Vol. 33(11). - P. 1171-1176. https://doi.org/10.1016/0020-708X(82)90242-3

4. Romei, C., Di Fulvio, A., Traino, C. A., Ciolini, R., \& d'Errico, F. Characterization of a low-cost PIN photodiode for dosimetry in diagnostic radiology//Physica Medica. - 2015.-Vol.31(1). P. 112-116. https://doi.org/10.1016/j.ejmp.2014.11.001

5. Oliveira, C. N. P., Khoury, H. J., \& Santos, E. J. P. PiN photodiode performance comparison for dosimetry in radiology applications // Physica Medica. - 2016. - Vol. 32(12). - P. 1495-1501. https://doi.org/10.1016/j.ejmp.2016.10.018 
6. Nazififard, M., Suh, K. Y., \& Mahmoudieh, A. Experimental analysis of a novel and low-cost pin photodiode dosimetry system for diagnostic radiology. Review of Scientific Instruments, 2016, Vol. 87(7). https://doi.org/10.1063/1.4955170

7. Paschoal, C. M. M., Souza, D. N., \& Santos, L. A. P. Characterization of three photodetector types for computed tomography dosimetry. World Academy of Science, Engineering and Technology, 2011, Vol. 80(8), pp. 92-95.

8. Damulira, E., Yusoff, M. N. S., Omar, A. F., \& Taib, N. H. M. A review: Photonic devices used for dosimetry in medical radiation. Sensors (Switzerland), 2019, Vol. 19(10), pp. 1-28. https://doi. org/10.3390/s19102226

9. Anđelkovi'c, M.S.; Risti'c, G.S. Feasibility study of a current mode gamma radiation dosimeter based on a commercial PIN photodiode and a custom made auto-ranging electrometer. Nucl. Technol. Radiat. Prot, 2013, Vol. 28, pp. 73-83.

10. Oliveira, C.N.; Khoury, H.J.; Santos, E.J. PiN photodiode performance comparison for dosimetry in radiology applications. Phys. Med, 2016, Vol. 32, pp. 1495-1501.
6. Nazififard, M., Suh, K. Y., \& Mahmoudieh, A. Experimental analysis of a novel and low-cost pin photodiode dosimetry system for diagnostic radiology // Review of Scientific Instruments. - 2016. Vol. 87(7). https://doi.org/10.1063/1.4955170

7. Paschoal, C. M. M., Souza, D. N., \& Santos, L. A. P. Characterization of three photodetector types for computed tomography dosimetry // World Academy of Science, Engineering and Technology. - 2011. - Vol. 80(8). - P. 92-95.

8. Damulira, E., Yusoff, M. N. S., Omar, A. F., \& Taib, N. H. M. A review: Photonic devices used for dosimetry in medical radiation // Sensors (Switzerland). - 2019. - Vol. 19(10). - P. 1-28. https://doi. org/10.3390/s19102226

9. Anđelkovi'c, M.S.; Risti'c, G.S. Feasibility study of a current mode gamma radiation dosimeter based on a commercial PIN photodiode and a custom made auto-ranging electrometer. Nucl // Technol. Radiat. Prot. - 2013. - Vol. 28. - P. 73-83.

10. Oliveira, C.N.; Khoury, H.J.; Santos, E.J. PiN photodiode performance comparison for dosimetry in radiology applications // Phys. Med. - 2016. - Vol. 32. - P. 1495-1501 